\title{
Chapter 9 \\ Fathers on Leave Alone in Iceland: Normal \\ Paternal Behaviour?
}

\author{
Ingólfur V. Gíslason
}

\subsection{Introduction}

The possibilities for Icelandic fathers to stay at home with their very young children changed dramatically at the turn of the century when they received a fairly long period of non-transferable parental leave. This took place as part of a radical transformation of the laws on parental leave. The consensus surrounding this change was remarkable as was the extent to which the fathers made use of their rights. Even though Iceland, as well as most of the western world, has seen substantial changes in gender relations in past decades, these changes mainly related to the situation of women which made inroad to traditional male areas. There have been few attempts to influence the situation of men so that they made inroad to traditional female areas such as child care. In fact there seems to have been a fairly broad consensus that men were not interested in partaking there or lacked the ability. Experience from Iceland and some of the other Nordic countries seems to indicate that the relatively little participation of men in the care for their own children may be more due to lack of real social possibilities than lack of interest or abilities. Still, even though statistics show an increase in the participation of fathers, we need many more studies of the situation of fathers that are active in taking care of very young children. In this study I focus on the experience of Icelandic fathers who have made extensive use of their rights and been at home alone with their child or children.

I.V. Gíslason $(\bowtie)$

Faculty of Social and Human Sciences, Iceland University, Gimli v/Sæmundargata, IS-101, Reykjavík, Iceland

e-mail: ivg@hi.is 


\subsection{Policy Context}

The year 2000 saw a radical change in opportunities for Icelandic fathers to make use of parental leave. The then sitting centre-right government presented a bill to the Icelandic parliament, Alpingi, which proposed a complete revolution of the existing system. The leave was extended in steps from 6 months to 9 and parents had 18 months to make use of their rights. Economic compensation was changed from a low flat rate benefit to $80 \%$ of wages and the compensation to those with little or no connection to the labour market was raised considerably. The prior 6 months long parental leave had in principle been dividable between parents but in reality only between 0.2 and $0.4 \%$ of fathers used any part of it each year. Now the leave was divided between parents, 3 months for each parent on a strict non-transferable basis, and 3 that they could divide as they liked. The system was flexible, leave can be taken on a part-time basis and parents can be at home together for a period or the whole time and both receive full economic compensation. A new Parental Leave Fund was established to monitor the system and it received its income mainly from an insurance levy paid by all employers. Alpingi proved to be enthusiastic about the project and the bill was passed unanimously without any changes (Eydal and Gíslason 2008).

Of course all this did not happen without context. Many political and social actors had criticised the parental leave system, pointing out for example that parental leave in Iceland was the shortest of the Nordic countries, economic compensation was far too low and the fact that only mothers used it was not in accordance with the gender equality project. The labour unions, women's organizations and (left-wing) political parties pressed for changes in the 1990s. Opinion polls had also revealed that Icelandic men wanted to reduce their working hours and spend more time with their families and they were ready to make use of parental leave as long as it did not infringe on the possibilities of mothers (Gíslason 2007).

The consensus in Alpingi was mirrored in Icelandic society. Opinion polls showed strong support for the changed system (Eydal and Gíslason 2008) and as a matter of fact this support has increased over the years. In 2003, 85.4\% of respondents stated that they were positive or very positive to fathers using 3-6 months parental leave. In a similar poll in $2012,88.6 \%$ were positive or very positive (Eydal and Gíslason 2014). Table 9.1 shows the development of use of the parental leave.

As Table 9.1 shows the great majority of Icelandic fathers use their right to parental leave, $82.4 \%$ the first year and around $90 \%$ after that before the cuts in economic compensation begin to take their toll. On average they use the time allotted to them, the time that only they can use (the figures refer to working days). As mentioned above the extension of the leave came in steps. In 2001 the fathers got their first month and used on average 39 days. The second month came in 2002 and that year fathers used on average 62 days and when the third month came in 2003 the average use rose to 97 days and has been around 100 days since. Mothers, on the other hand use on average their 3 months and the 3 sharable, averaging around 
Table 9.1 Development of the use of parental leave in Iceland 2001-2012

\begin{tabular}{|c|c|c|c|c|c|c|c|c|}
\hline Year of birth & 2001 & 2003 & 2005 & 2007 & 2009 & 2010 & 2011 & 2013 \\
\hline Mothers (n) & 4054 & 4167 & 4302 & 4555 & 4965 & 4817 & 4406 & 4197 \\
\hline $\begin{array}{l}\text { Applications } \\
\text { from fathers as } \\
\% \text { of } \\
\text { applications } \\
\text { from mothers }\end{array}$ & $82.4 \%$ & $86.6 \%$ & $88.2 \%$ & $88.5 \%$ & $85.8 \%$ & $83.5 \%$ & $80.3 \%$ & $79.9 \%$ \\
\hline $\begin{array}{l}\text { Average number } \\
\text { of days used by } \\
\text { fathers }\end{array}$ & 39 & 97 & 99 & 101 & 98 & 92 & 86 & 87 \\
\hline $\begin{array}{l}\text { Average number } \\
\text { of days used by } \\
\text { mothers }\end{array}$ & 186 & 183 & 184 & 181 & 178 & 179 & 179 & 181 \\
\hline $\begin{array}{l}\text { Fathers using } \\
\text { more than their } \\
\text { basic rights }\end{array}$ & $14.5 \%$ & $16.1 \%$ & $19.5 \%$ & $21.2 \%$ & $20.1 \%$ & $17.1 \%$ & $14.7 \%$ & $15.0 \%$ \\
\hline $\begin{array}{l}\text { Mothers using } \\
\text { more than their } \\
\text { basic rights }\end{array}$ & $94.2 \%$ & $90.9 \%$ & $89.7 \%$ & $93.1 \%$ & $92.9 \%$ & $95.3 \%$ & $95.5 \%$ & $96.1 \%$ \\
\hline $\begin{array}{l}\text { Fathers using } \\
\text { less than their } \\
\text { basic rights }\end{array}$ & $5.1 \%$ & $14.2 \%$ & $19.5 \%$ & $16.4 \%$ & $19.3 \%$ & $30.0 \%$ & $39.7 \%$ & $36.5 \%$ \\
\hline $\begin{array}{l}\text { Mothers using } \\
\text { less than their } \\
\text { basic rights }\end{array}$ & $0.9 \%$ & $1.0 \%$ & $0.1 \%$ & $1.5 \%$ & $1.0 \%$ & $0.8 \%$ & $1.1 \%$ & $0.8 \%$ \\
\hline
\end{tabular}

Sources: Fæðingarorlofssjóður (2010) and Fæðingarorlofssjóður (n.d.)

180 days. This confirms experience from other countries, a sharable time becomes a time for the mother (Duvander and Lammi-Taskula 2011).

However, averages can hide a great deal. As Table 9.1 shows the share of fathers not making use of all their time increased as their days increased. When they had only 1 month $5.1 \%$ of those who used some parental leave did not make full use of their time. This rose to $10.1 \%$ when the second month was added and to $14.2 \%$ when the third month was in place. Since then it was between $16 \%$ and $20 \%$ before the cuts in economic compensation.

The other side of the coin is that a substantial number of fathers use some (or all) of the sharable time. The first year $14.5 \%$ of fathers used more than their time. This figure rose slowly and was around $20 \%$ before the cuts. As far as I know only one study has so far looked at couples where the father has taken longer leave than the mother (Gíslason 2005). This was a qualitative study of nine couples and among them the labour market situation of the mother was the deciding factor regarding the unusual sharing of the parental leave. The mothers mostly worked independently as lawyers, architects or writers or were placed very high in the hierarchy where they were employed. The mothers felt that they could not leave the labour market completely for long and this seemed to open up spaces for negotiations and the fathers 
stepped in. But it should also be added that all the mothers had experienced being frowned upon by their immediate surroundings and being told, directly or indirectly that this was not something a "good mother" does.

One of the reasons for the extensive use of the leave by Icelandic fathers is probably the general social support which extended into the ranks of individual employers. Opinion polls have shown that even though employers are the social group most negative to fathers being on parental leave, $73.7 \%$ were positive in 2003 and $81 \%$ in 2012 (Eydal and Gíslason 2008, 2014). Similarly a quantitative survey in 2006 among parents showed that $89.1 \%$ of fathers had met very positive, positive or neutral reactions from their superiors when announcing their intention to take paternal leave. To be sure, more fathers (10.9\%) than mothers $(4.8 \%)$ had experienced negative or very negative reactions (Jónsdóttir 2007) but it still seems like employers attitudes should not be a major hindrance for a father that wants to make use of his right to leave.

Originally there was no ceiling on economic compensation while on leave. Parents received $80 \%$ of salary regardless of how high it was. Social pressure led to the introduction of a very high ceiling in 2004. It was so high that it only affected $2.6 \%$ of fathers and $0.4 \%$ of mothers (Fæðingarorlofssjóður 2010). In 2008 the Icelandic financial system collapsed and the following years saw a number of cuts in the welfare budget. Among the measures was a lowering of the ceiling on economic compensation during parental leave. This was done three times which meant that in 2010 the ceiling affected $45.7 \%$ of fathers and $19 \%$ of mothers (Fæðingarorlofssjóður 2010). This led to a fall in the usage by fathers but there are indications that they are spreading the leave over a longer period and take shorter spans.

In a world-wide perspective Iceland can be regarded as a fairly gender equal welfare society. The labour market participation of women is very high (78.5\%), political representation fairly good $(40 \%$ in the Icelandic parliament and $44 \%$ in the municipalities) and opinion polls show strong support for the idea of gender equality. For 7 consecutive years Iceland has occupied first place in the yearly international survey on gender equality by the World Economic Forum (World Economic Forum 2015). Other research has also revealed that changes have been taking place in the domestic sphere both as regards housework and child care, with men increasing the hours they put in and these aspects of life being subjected to negotiations rather than being automatically resigned to the woman (Arnalds et al. 2013; Gíslason 2009; Stefánsson and Pórsdóttir 2010).

One study in particular illustrates this, namely the one by Arnalds et al. (2013). Three times parents who had their first child in a particular year have been asked to fill in a diary to show their participation in the labour market, their division of domestic labour and childcare for 1 year before the child was born and every month until it is 3 years old. This was done for children born in 1997, 2003 and 2009, the first cohort being born 3 years before the new law on parental leave, the second was the first to have the full benefit of the changes and the third was born after the serious cuts in economic compensation. The results all point in the same direction. After the change mothers return earlier to the labour market, they are closer to 
having reached their pre-birth working hours when the child is 3 and, last but not least, there has been a marked increase in the sharing of child care not only during parental leave but for the 3 years after birth for which the diary was held. When the children born in 1997 were 3 years old $36 \%$ were cared for evenly by their fathers and mothers, for children born 2003 and 2009 the figures were 49\% and 59\% respectively. This is in line with results from other countries, showing that fathers that are active from the beginning continue to shoulder a greater share of child care than those who have not been very active while the child was very young (Kitterød 2013; Nepomnyaschy and Waldfogel 2007; Rege and Solli 2010; Tanaka and Waldfogel 2007). While not claiming that this is solely due to the impact of the new parental leave a comparison of parents where the fathers took parental leave and those where he did not show much more involvement from those fathers that used parental leave (Arnalds et al. 2013).

The main hindrance for the effectiveness of the divided parental leave in Iceland in the striving for gender equality is the so-called 'care gap', the period from the end of the parental leave and to a place in kindergarten. There is a shortage of kindergarten places and children are usually between 18 and 24 months old when they are admitted. This is a period where parents have to seek individual solutions (Farstad 2012). Research shows a variety of strategies but private child minders is the most usual. The main problem there is that they are much more expensive than kindergartens and for those in low-paid jobs it doesn't always pay to return to the labour market if a private child minder is necessary. And whether or not that is the explanation we also see in this research that mothers more often than fathers adjust their labour market participation to bridge this gap. Either they do not return to the labour market or they do so on a part-time basis (Jónsdóttir 2007; Ingólfsdóttir 2013).

\subsection{Participants}

The ten fathers that were interviewed for this study were found by advertising on Facebook and by word of mouth (see Table 9.2). The aim was to find fathers who showed some diversity in education and work, particularly to get fathers from both the private and public labour markets. As it turned out there are two fathers with student exam, two craftsmen and six with a university degree. Six of them work in the private sector. All except one had taken 3 or more months of parental leave. All their partners except one, have university degrees and all except two work in the public sector. The interviews were all held in my office at the University of Iceland.

The interviews lasted between 40 to $90 \mathrm{~min}$. They were taped and then fully transcribed and analysed, themes identified and compared using the methods described in textbooks on qualitative methods (Kvale and Brinkman 2009; Hennink et al. 2010; Silverman 2013). Naturally, a number of themes came from the questions themselves but other emerged directly from the narratives such as the importance of the will of the mothers and the importance of the care gap. 
Table 9.2 Characteristics of the participating fathers and their partners

\begin{tabular}{|c|c|c|c|c|c|}
\hline Father & Age & Children & $\begin{array}{l}\text { Leave with } \\
\text { youngest child }\end{array}$ & $\begin{array}{l}\text { Education/ } \\
\text { employment }\end{array}$ & Partner \\
\hline 1 & 31 & $\begin{array}{l}3 \text { boys, } 8 \\
\text { months, } 3 \text { and } \\
13 \text { years (the } \\
\text { oldest is not his } \\
\text { biological son) } \\
\end{array}$ & $\begin{array}{l}2 \text { weeks summer } \\
\text { vacation }+3 \\
\text { months parental } \\
\text { leave }\end{array}$ & $\begin{array}{l}\text { Student exam, } \\
\text { works for a } \\
\text { computer store as a } \\
\text { purchaser and } \\
\text { teacher, } 45 \mathrm{~h} / \mathrm{w}\end{array}$ & $\begin{array}{l}\text { 32, MA } \\
\text { (humanities), } \\
\text { elementary } \\
\text { school teacher } \\
40 \mathrm{~h} / \mathrm{w}\end{array}$ \\
\hline 2 & 35 & $\begin{array}{l}1 \text { girl (1) } \\
\text { together, she } \\
\text { has } 3 \text { from an } \\
\text { earlier } \\
\text { relationship, } \\
\text { living with them } \\
\end{array}$ & $\begin{array}{l}1 \text { month summer } \\
\text { vacation }+3 \\
\text { months parental } \\
\text { leave }\end{array}$ & $\begin{array}{l}\text { Printer, service } \\
\text { adviser, } 45 \mathrm{~h} / \mathrm{w}\end{array}$ & $\begin{array}{l}\text { 37, elementary } \\
\text { school teacher, } \\
40 \mathrm{~h} / \mathrm{w}\end{array}$ \\
\hline 3 & 31 & $\begin{array}{l}2 \text { boys, } 1 \text { and } 5 \text {, } \\
\text { the older is not } \\
\text { his biological } \\
\text { son }\end{array}$ & $\begin{array}{l}3 \text { months parental } \\
\text { leave, the first } \\
\text { with the mother }\end{array}$ & $\begin{array}{l}\text { Student exam, } \\
\text { system } \\
\text { administrator, } 40 \\
\mathrm{~h} / \mathrm{w}\end{array}$ & $\begin{array}{l}\text { 30, university } \\
\text { exam (business), } \\
\text { sales manager, } \\
40 \mathrm{~h} / \mathrm{w}\end{array}$ \\
\hline 4 & 34 & 2 girls, 2 and 5 & $\begin{array}{l}1 \text { month parental } \\
\text { leave }\end{array}$ & $\begin{array}{l}\text { University exam } \\
\text { (humanities), } \\
\text { manager, } 45 \mathrm{~h} / \mathrm{w}\end{array}$ & $\begin{array}{l}33, \text { social } \\
\text { worker, public } \\
\text { servant. } 40 \mathrm{~h} / \mathrm{w}\end{array}$ \\
\hline 5 & 37 & 2 girls 3 and 6 & $\begin{array}{l}6 \text { months parental } \\
\text { leave }\end{array}$ & $\begin{array}{l}\text { Engineer, program } \\
\text { developer, } 40 \mathrm{~h} / \mathrm{w}\end{array}$ & $\begin{array}{l}\text { 43, MA (social), } \\
\text { public servant }\end{array}$ \\
\hline 6 & 40 & $\begin{array}{l}2 \text { boys (13 and } \\
3 \text { ) and one girl } \\
(11)\end{array}$ & $\begin{array}{l}2 \text { weeks company } \\
\text { paid leave }+7 \\
\text { months parental } \\
\text { leave }\end{array}$ & $\begin{array}{l}\text { MA (physical } \\
\text { science), research } \\
\text { and development, } \\
45 \mathrm{~h} / \mathrm{w}\end{array}$ & $\begin{array}{l}41, \mathrm{PhD} \\
\text { (social), public } \\
\text { servant }\end{array}$ \\
\hline 7 & 29 & $\begin{array}{l}1 \text { boy, } 15 \\
\text { months }\end{array}$ & $\begin{array}{l}1 \text { month parental } \\
\text { leave }+4 \text { months } \\
\text { parental leave }\end{array}$ & Physician, $65 \mathrm{~h} / \mathrm{w}$ & $\begin{array}{l}\text { 29, Physician, } \\
\text { phd student }\end{array}$ \\
\hline 8 & 40 & Boy (3), girl (6) & $\begin{array}{l}1.5 \text { months } \\
\text { summer } \\
\text { vacation }+3 \\
\text { months parental } \\
\text { leave }\end{array}$ & $\begin{array}{l}\text { MA (social), } \\
\text { director with a small } \\
\text { research institute, } \\
50 \mathrm{~h} / \mathrm{w}\end{array}$ & $\begin{array}{l}43, \text { social } \\
\text { worker, } 50 \%\end{array}$ \\
\hline 9 & 35 & $\begin{array}{l}2 \text { boys }(4 \text { and } 8) \\
\text { and one girl } \\
(11)\end{array}$ & $\begin{array}{l}2 \text { weeks parental } \\
\text { leave }+3 \text { months } \\
\text { parental leave }\end{array}$ & $\begin{array}{l}\text { BA computer } \\
\text { science, } \\
\text { programmer, } 40 \mathrm{~h} / \mathrm{w}\end{array}$ & $\begin{array}{l}35, \text { artist and } \\
\text { shop assistant }\end{array}$ \\
\hline 10 & 38 & 1 boy (3) & $\begin{array}{l}3 \text { weeks parental } \\
\text { leave }+2.5 \text { months } \\
\text { parental leave }\end{array}$ & Carpenter, $50 \mathrm{~h} / \mathrm{w}$ & $\begin{array}{l}\text { BA (language), } \\
\text { advertising } \\
\text { planner }\end{array}$ \\
\hline
\end{tabular}

\subsection{Main Themes and Findings}

\subsubsection{General}

None of the fathers that I interviewed seemed to experience what he had done as something out of the ordinary. Most of them came to the interview because their partners had asked them to do it. The women were proud of their husbands; the 
husbands seemed not to really understand what all the fuss was about. Their general views were that they had wanted to do this, circumstances favoured the division they had settled on and they had no misgivings, were pretty confident that they could handle this. None seemed to think that this was "un-manly" or that he was engaged in some form of gender subversion though none had experienced anything similar as a child. These were just "different times". Many were genuinely surprised when I asked them if they had experienced this as something incompatible with a masculine role: "No it never occurred to me that what I was doing was something unmanly. Why on earth should that be?" [9]

The experience of one family [3] illustrates the general trend. The couple has one child together and the woman has one from an earlier relationship that lives with them. Both work on the private market. Their son was almost 1 year old when I interviewed the father. The first month after birth both parents were on leave. After that the father returned to work and the mother was on leave for 7 months. For 5 of those months she also worked $20 \%$ and by doing that she managed to stretch the leave. When she returned to full-time work the father took over on a full-time basis for the 2 months he had left of his leave. Asked about the reasons, he began by stating that they had wanted the child to have as much time with the mother as possible and that breastfeeding should be for at least 6 months and then added: "It was also that I wanted to have some time with them together and then just with him."

When I interviewed him the child had recently begun with a child minder (a male, which is highly unusual) and they were all very pleased with that person even though the couple looks forward to getting a place in kindergarten for their son. When I asked if it had not been an option to stretch the leave period even more to a similar reduction in compensation he said that financially that had not been possible.

And these were the general reasons behind fathers being home alone for a relatively long period. The whole family is at home together for the first couple of weeks or even longer. This is the period when they are all getting to know each other in their new roles and a period where the mother needs rest so that is the main role of the father, keeping family and friends at bay and making sure that the mother is not overburdened by domestic chores. Then the fathers return to the labour market and return to the domestic life after 6-8 months to cover as much as possible of the period until a place in kindergarten becomes available.

It was natural in all cases that the mother should be at home for at least 6 months both because of breastfeeding and because the parents deemed that important to ensure a good bonding between mother and child. After that period there was increased room for negotiations and individual solutions. But these were always with one goal in mind, namely to delay as much as possible the time when the child would have to be put into other peoples care. What was mainly to be avoided was to use private child minders. Some were uncomfortable with the thought that there was only one grown person taking care of up to five infants while others were more concerned with the costs. The labour market situation of the mother played a role (when was it necessary for her to return to work) but all the fathers added that they had wanted to do this in order to better bond with the child. In some cases that 
aspect had also been explicitly stated by the mothers when they were urging the fathers to make use of their leave in this fashion or supporting their wish to do so.

There were cases where this had not been planned from the beginning but changed circumstances made it an option or even necessary. In one case [7] both the parents are young doctors. They had planned for her to take a fairly long leave, 10-11 months "because she felt that it was important that he didn't have to go to a child minder or to kindergarten too early." The plan was that the father would take 1 month immediately after birth (which he did) and then take the remaining 2 months during the summer while she was still on leave. However, a job opportunity arose after 7 months and she applied and got it. Then he stepped in and was on leave for 4 months. He added:

But I think that I had voiced this possibility early on or stated that I had nothing against being home alone... So when we were first discussing this we talked about whether she should take six and then I would take over and be at home for three... and I stated that I was game for anything but... I think that she just didn't originally want to miss anything you know... and we could afford her being at home for so long so she thought it better that we should be at home together. [7]

This is in line with other qualitative studies on young parents in Iceland. The mothers are the ones who lay the ground rules in this area and the fathers go along (Gíslason 2005; Ingólfsdóttir 2013). Not that the fathers do not have opinions or that the division of the leave is not discussed, but in the great majority of cases it seems that the mothers state what they want to do themselves and what they want the fathers to do and that becomes their shared decision. If something changes with the situation of the mother then that can change what has been decided and the fathers do not seem reluctant to go home.

It appeared from the interviews that most of these mothers were interested in having the fathers at home for a period of time so that they could better bond with their children. In one case the father had not intended to take any parental leave but his wife insisted that he did:

\footnotetext{
She pushed very hard that I should take leave and I am really very grateful for that period... but financially it could have ended in a disaster but it worked out, it always does in the end.

Q. Why did your wife insist that you took leave?

A. It was about the bonding, bonding with the child. She felt that it was important if I somehow hadn't developed contact before we had to let the child to a child minder or kindergarten. [4]
}

In a similar vein the fathers were not at all sure if this experience had had any positive effects on their relationship with the mothers but were all pretty sure that if they had not been ready to take their share that would have affected the relationship in a very negative way:

It would have created conflicts if I had demanded or refused to do this or something like that but that was never any... not that I was forced into this you know... it was just natural but if I had been... probably would have created pressure on her if I had... been dissatisfied... but then of course she wouldn't be with me in the first place if I was some kind of a male chauvinist. [6] 
Still, in all the cases the fathers were doing something that was completely different from what their own fathers had done. Usually their fathers had been traditional men of their generation, hard-working and not much at home. Though they had helped with the domestic chores "help" is the defining word. They were very much in lieu with what was seen as masculine in their days. On the other hand the fathers in this study were now doing what society as a whole encouraged them to do. They have the legal support, the general discourse is supportive, friends and relatives are supportive and their partners both want and expect them to do this. It really should not be all that difficult.

\subsubsection{Employers, Co-Workers, Friends and Relatives}

None of the men had experienced any negative reactions at their workplace due to their long leave, neither when they told their superiors about their plans, nor when they returned to work. It did not matter whether they were working for a private company or in the public realm, all reported similar reactions, good wishes and that of course they should take their leave as they wanted to. None of them expected anything else, they knew that this was their right and of course it would be acknowledged. Why on earth not? In most cases their workplace had already experienced something similar. In one case the father had only been working with the company for a month when he told his superiors about his intentions to take 3 months parental leave. "And they just congratulated me and I got all the support I could have wished for." [3] His wife had a similar experience. Four months pregnant she applied for a new job, told about her pregnancy at the interview and that she would take 6-7 months parental leave. That was no problem and she got the job.

The attitude among their colleagues, friends and relatives were similar. Except for a few among the grandparents no one saw what the fathers were doing as something strange or were worried that they would not be able to handle it. There were voices of envy but no derogatory remarks or jokes that were experienced as offensive. One father had taken 3 months parental leave following his partners 6 months:

I never experienced that this was something out of the ordinary. My friends and relatives were all with me in this, thought it was natural and fine. At least when they talk to me, I don't know what they say elsewhere (laughs). It's just... this seems to be the view, at least with this generation, that this is natural and maybe some think that it is... yes it is more that people talk about this as a privilege... you know, to be able to do this and maybe some envy connected to that, but I have never experienced any adversity or that this was something I should not do. [1]

As was pointed out in the introduction there has been a remarkable political and social consensus around the system of parental leave in Iceland so it is really not that surprising that even fathers who have taken longer leave than the average or have taken it mainly alone home do not experience any negativity. Still, it is interesting to see the support and encouragement that fathers who are breaking (relatively) new ground seem to receive from their social surroundings. Perhaps not all that 
surprising in the light of the general development in Iceland towards the dissolving of traditional gender roles.

\subsubsection{Instructions from Partners}

Even though both partners had agreed on how to share the leave, the majority of the fathers experienced that their partners instructed them on what to do in the daily routine or phoned to make sure they were doing the right things at the right moments. This was mainly in the beginning of their leave. The men, however, did not seem to mind all that much. For one thing the mothers had been at home with the babies for some months, knew and had helped establish the daily routines. It was simply natural that they briefed the fathers about the children's eating and sleeping habits. But even when the "interference" was more than this the men realized that this was not really a lack of trust in their abilities to care for the baby but just a natural wish by the mothers to stay in touch with the children and their daily progress.

One of the men explained:

She was in constant touch, you name it, how she had slept and eaten and all that... you know... how to approach this and that and things that you get from your wife when she has been at home with the child for nine or ten months... there are not all that many tricks but I got my formula from the wife, how to best approach this and that. [4]

No she wasn't worried or anything like that but they still... they, of course have this... that they have this maternal instinct that they know best and of course often they do know a whole lot better, you know so... in the beginning they want to look over your shoulder. [8]

None of the men themselves had experienced any major doubts about their abilities to handle the task regardless of whether they had any prior experience of handling an infant or not. For one thing they had been at home with mother and the child for between 2 and 4 weeks following the birth. They had also been with the child during evenings, nights and weekends. They had participated in changing diapers, bathing and feeding the child and putting it to sleep. There was nothing really new about all this. What was new was that there was no one around to ask or confer with. But they were all certain that this was something they could easily handle though some admitted to a slight knot in their stomach the first day.

\subsubsection{Enjoyable and Difficult Moments}

Asked about if they recalled any particularly enjoyable moments not many could name something specific. They enjoyed a daily routine that was so much different from what they were used to in their working life and they enjoyed taking care of the child. This was particularly for the first few weeks that they were home alone. Some (but not all) said that towards the end of the period, life had become tedious 
and they were ready to start working again. Some mentioned that their partners had expressed similar views. But there were two general enjoyable parts that popped up. One was the joy of being the first to see or experience the child doing something new, experiencing the progress first. The first step, the first word, were moments that stood out. Some also mentioned that these moments also stood out for the parent that was not there to see it. The mothers felt as if they had been let down or cheated upon by not being there when this happened the first time.

She took her first steps while with me, that stands out. And she said her first word while I was with her... her mother wasn't all that pleased that she had not been there (laughs), this stands out. [2]

I get to experience what he is doing for the first time, I am with him, just the little things you know, nothing big but taken together it is just so positive to have been there to experience this period in his life. [1]

The second part was the experience that the child trusted them, sought their company no less than its mother if both were present or even preferred the fathers. In one case the couple had three children and the father had been at home with the youngest for 7 months.

He was very much a 'daddy's boy' and... his mother began a very conscientious campaign to regain her position when she got that chance and has worked continuously on that ever since. Successfully and I haven't interfered in any way... but this is now much more even. If he starts crying it's not just running to mom, it is more even and some days he just wants his mom and other days he just wants his dad so... this is different than with the other children. [6]

\subsubsection{Negative Experiences}

When asked about negative experience there was some diversity in the answers. Some had experienced social isolation and went on about how much easier it seemed to be for mothers to break out of the isolation. To begin with, the mothers had sometimes bonded with other expecting women in pre-natal courses and sometimes had formed a group on Facebook that they used to discuss their experience as well as planning outings and social gatherings. Then there are organized "mother-mornings" in some of the churches in Reykjavík (Iceland's capital) and even though fathers are officially welcome only one had given it a try and he did not enjoy the experience. And finally there are simply more women than men at home during daytime. But the isolation was on the whole not a major issue and in some cases brought about enjoyable new experience:

Well obviously you experience isolation when you are at home and all others are working... I met with a lot of people that I usually would not meet. I very often took him to see all his grandparents and aunts and cousins and so on, people that I usually would not visit without a specific reason. You just went when you knew that someone was at home. So this of course is one indication of isolation that you start looking for new company... even though that company was also very enjoyable. [7] 
Those whose children had trouble sleeping at night of course mentioned that weeks or even months without one night of uninterrupted sleep were a very difficult and negative experience. But this was very rare and generally there was nothing really negative about the whole thing.

\subsubsection{What were They Doing?}

A recurrent theme in general discussions on parental leave in Europe is that the fathers are not really doing what they are supposed to be doing while on leave. They are moose hunting, playing golf, or repairing the house depending on what country you are in. Usually this is just phantasy, studies reveal no such trend though doubtlessly examples can be found. Some of the fathers that I interviewed had worked part-time during their parental leave but so had some of the mothers. Usually this was in order to be able to extend the leave period so that they either worked while the child slept during the day or in the evening when the partner was at home. But generally the fathers just did what mothers and housewives have done, they took care of the child or children and they did the domestic chores. One of the fathers [10] described it thus:

When I was at home with her I took completely care of the home, I did the laundry, cleaned up, vacuumed and scrubbed and dusted and tried to have the home nice looking when she came home.

\subsubsection{Domestic Chores}

As for the general division of labour within the household all of the men claimed an equal division though in the one case where the mother was working part-time she naturally did more than he. In general the division had not been explicitly discussed or decided upon. It was more a case of day-to-day division based on working hours, which one could pick up the children from kindergarten and sometimes schools, which one had taken the car to work and could therefore shop and so on.

The men stated that usually there was little or no argument about who should do what but they also said that they knew that their partners would not stand for any show of chauvinism or laziness on the home front. It was a given from the beginning of the relationship that the division of house tasks should be equal and the men had no trouble accepting that. In fact they regarded it as natural. Still, I am pretty sure that if the women would want to shoulder the lion's share of the domestic labour in most (but not all) cases that too would be accepted. Women call the shots in this area in most cases. However, there were some traditional divisions, the men took care of the traditionally male chores. They repaired in the house, mowed the lawn and washed and repaired the car. 
The general view among the fathers seemed to be that there is no naturally gendered division of domestic labour, these things just have to be done and it is only fair that they should be shared. Similarly, that when only one in a couple is in the labour market then it is only fair that the other should shoulder domestic work. Similar views were also present in a yet unpublished qualitative study of couples where the man had been unemployed for at least 3 months while his partner was working fulltime. I interviewed ten couples separately and with one exception they all agreed that the man had greatly increased his share of the domestic labour, in most cases just taking completely over. And, in the same way as in this study, the operating word was "fair". It was generally agreed that the total hours in paid and unpaid labour should be close to equal in couples, anything else was simply "unfair".

The protective element towards their partner also often popped up. The fathers tried to make sure that their partner got enough sleep and was able to meet with her friends, pursue hobbies and so on.

\subsubsection{Learning from the Experience}

The majority of the fathers worked more than full-time, if full-time is defined as 40 $\mathrm{h}$ a week. The average working week for Icelandic men is $44 \mathrm{~h}$ and for men between 25 and 54 years old it is almost $48 \mathrm{~h}$ a week. So these men were pretty average in that realm. All the mothers except one were working full-time. Whether it can be called learning or something else two of the men mentioned that they were changing their jobs (within their firm) to reduce their working hours in order to be more with their families.

I want to be more at home, to participate more in the shopping and cooking and other things in my home. [2]

Another said that neither he nor his wife were interested in working more than the prescribed $40 \mathrm{~h}$ a week even though that was a possibility in both workplaces. "We just decided to stay out of that." [3]

\subsubsection{What the Leave Should Look Like}

All of the men brought up the same problem regarding the parental leave and child care namely the care gap. And whatever their opinion on how parental leave should look like, they all stated that some system of (public) child care should be available when that period was over. The period of having to rely on assistance from friends and close relatives to care for the child was seen as highly stressful and in fact unacceptable. The system of private child minders to cover this period was by most seen as unsatisfactory, much too expensive and many also felt that it was too much of a lottery to hand your child over to a person you knew little about and who worked alone. 
They were mostly satisfied with the parental leave system as it is. No one wanted to abolish the non-transferable periods so the family could "freely" choose how it was divided. On the other hand they hadn't really given this much thought, the system was as it was and you just deal with it on that basis. When asked directly if the division of the leave should be left to individual families most were of the opinion that it was good to have some division.

I think it is good to have some division, some basic division... just as an encouragement to share things equally. [7]

\subsection{Conclusions}

For the last decades Iceland has been experiencing an increased dissolution of traditional gender roles as indeed most of the western world has. The social situation of women has greatly changed with increased participation on the labour market, a (slowly) diminishing gender pay gap and increased number of women in seats of power. All of this is a general development in the West. What is perhaps more unusual are efforts from the public authorities to influence the traditional roles of men in the home and particularly regarding child care.

Even though the changes in masculinity roles in Iceland had begun much earlier they really took off with the changed law on parental leave in 2000. Here was a law that not only gave fathers the possibilities to take parental leave and care for their infants, it expected them to do so, they could not write the period over to the mother. Judging by official statistics and the studies that have been carried out so far, fathers embraced the possibilities and their usage of the leave is initiating or supporting other changes such as the more equal division of household tasks and the labour market participation of men and women.

This pattern is mirrored in the study presented here. The fathers that been alone with their children for an extensive period of time did not experience what they had done as something all that special. And in reality nothing in their social surroundings gave them reason to think otherwise. Telling their superiors about their intentions they were congratulated and told that naturally they should take the leave as they had intended. Co-workers, friends and relatives echoed this view. They themselves were willing to shoulder the task, having no or little misgivings about their abilities to take care of their children and certainly not experiencing what they were doing as something "un-manly" or not in accordance with some pre-given ideas about masculinities. In fact they found that idea laughable.

In conclusion, the evidence of this study seems to indicate that a lot can be achieved to subvert traditional gender roles by laws that are gender sensitive and take it as a given that both genders can perform well in roles and tasks that traditionally belong to the other gender. 


\section{References}

Arnalds, Á., Eydal, G. B., \& Gíslason, I. V. (2013). Equal rights to paid parental leave and caring fathers- the case of Iceland. Stjórnmál og stjórnsýsla, 9, 323-344.

Duvander, A., \& Lammi-Taskula, J. (2011). Parental leave. In I. V. Gíslason \& G. B. Eydal (Eds.), Parental leave, childcare and gender equality in the Nordic countries. Copenhagen: Nordic Council of Ministers.

Eydal, G. B., \& Gíslason, I. V. (2008). Paid parental leave in Iceland - History and context. In G. B. Eydal \& I. V. Gíslason (Eds.), Equal rights to earn and care - Parental leave in Iceland. Reykjavík: Félagsvísindastofnun Háskóla Íslands.

Eydal, G. B., \& Gíslason, I. V. (2014). Caring fathers and parental leave in prosperous times and times of crisis: The case of Iceland. In G. B. Eydal \& T. Rostegaard (Eds.), Fatherhood in the North. Bristol: Polity Press.

Farstad, G. R. (2012). Når omsorgsgapet skal dekkes: Islandske foreldres kjønnede omsorgsstrategier [Bridging the care gap. Gendered solutions of Icelandic parents]. Nordisk Barnehageforskning, 5(5), 1-11.

Fæðingarorlofssjóður. (2010, 2011). Samantekt yfir tölulegar upplýsingar Faðingarorlofssjóðs 2001-2010 [Statistical information from the Parental Leave Fund 2001-2010]. Available at http://www.faedingarorlof.is/files/Sk\%FDrsla\%20-\%20T\%F6lulegar\%20uppl\%FDsingar\%20 F\%E6\%F0ingarorlofs_sj\%F3\%F0s\%20fr\%E1\%202001-2009_587989908.pdf. Accessed 20 Sept 2014, 20 Sept 2015.

Fæðingarorlofssjóður. (n.d.). Unpublished data from the Maternity/Paternity Leave Fund.

Gíslason, I. V. (2005). Feður sem taka lengra fæðingarorlof [Fathers who take longer parental leave]. In Ú. Hauksson (Ed.), Rannsóknir í félagsvísindum VI [Social research VI]. Reykjavík: Félagsvísindastofnun Háskóla Íslands.

Gíslason, I. V. (2007). Parental leave in Iceland. Bringing the fathers in. Akureyri: Centre for Gender Equality.

Gíslason, I. V. (2009). Gender changes in Iceland: From rigid roles to negotiations. Arctic and Antarctic, 3(3), 121-149.

Hennink, M., Hutter, I., \& Bailey, A. (2010). Qualitative research methods. New York: Sage.

Ingólfsdóttir, E. (2013). Det löser sig. En studie om hur isländska föräldrar överbygger omsorgsgapet mellan föräldraledighet och förskola [It will work out. A study on how Iceland parents bridge the care gap from parental leave to kindergarten]. Unpublished MA thesis. University of Lund. Department of Sociology.

Jónsdóttir, B. (2007). Upplifun foreldra á faðingarorlofi [The experience of parents on parental leave]. Unpublished MA-thesis. University of Iceland.

Kvale, S., \& Brinkmann, S. (2009). Interviews: Learning the craft of qualitative research interviewing. Los Angeles: Sage.

Kitterød, R. H. (2013). Mer familiearbeid og mindre job blant smabårnsfedre [More domestic work and less paid work among fathers of young children]. In B. Brandth, \& E. Kvande (Eds.), Fedrekvoten og den farsvennlige velferdsstaten (pp. 42-58). Oslo: Universitetsforlaget.

Nepomnyaschy, L., \& Waldfogel, J. (2007). Paternity leave and fathers' involvement with their young children. Community, Work \& Family, 10(4), 427-453.

Rege, M., \& Solli, I. F. (2010). The impact of paternity leave on long-term father involvement. Stavanger: University of Stavanger.

Silverman, D. (2013). Doing qualitative research: A practical handbook. New York: Sage.

Stefánsson, K., \& Pórsdóttir, P. K. (2010). Ánaegja með fjölskyldulíf fyrir og eftir bankahrun [Satisfaction with family life before and after the bank crash]. Reykjavík: Pjóðmálastofnun Háskóla Íslands, fréttabréf nr. 8. Available at http://thjodmalastofnun.hi.is/sites/thjodmalastofnun.hi.is/files/frettabref_thjodmalastofnunar_8_2010.pdf. Accessed 24 Oct 2014. 
Tanaka, S., \& Waldfogel, J. (2007). Effects of parental leave and work hours on fathers' involvement with their babies. Evidence from the millennium cohort study. Community, Work \& Family, 10, 409-426.

World Economic Forum. (2015). The global gender gap report 2015. Available at http://www3. weforum.org/docs/GGGR2015/cover.pdf. Accessed 31 August 2016.

Open Access This chapter is licensed under the terms of the Creative Commons AttributionNonCommercial 2.5 License (http://creativecommons.org/licenses/by-nc/2.5/), which permits any noncommercial use, sharing, adaptation, distribution and reproduction in any medium or format, as long as you give appropriate credit to the original author(s) and the source, provide a link to the Creative Commons license and indicate if changes were made.

The images or other third party material in this chapter are included in the chapter's Creative Commons license, unless indicated otherwise in a credit line to the material. If material is not included in the chapter's Creative Commons license and your intended use is not permitted by statutory regulation or exceeds the permitted use, you will need to obtain permission directly from the copyright holder.

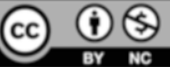

